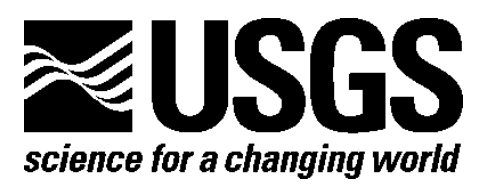

\title{
Soil Data from Different-Age Picea mariana Stands near
}

\section{Delta Junction, Alaska}

By Kristen L Manies and Jennifer W. Harden

Open-File Report 2011-1061 


\section{U.S. Department of the Interior \\ KEN SALAZAR, Secretary}

\section{U.S. Geological Survey \\ Marcia K. McNutt, Director}

U.S. Geological Survey, Reston, Virginia 2011

For product and ordering information:

World Wide Web: http://www.usgs.gov/pubprod/

Telephone: 1-888-ASK-USGS

For more information on the USGS-the Federal source for science about the Earth,

its natural and living resources, natural hazards, and the environment:

World Wide Web: http://www.usgs.gov/

Telephone: 1-888-ASK-USGS

Suggested citation:

Manies, K.L., and Harden, J.W., 2011, Soil data from different-age Picea mariana stands near Delta Junction, Alaska: U.S. Geological Survey Open-File Report 2011-1061 [http://pubs.usgs.gov/of/2011/1061/].

Any use of trade, product, or firm names is for descriptive purposes only and does not imply endorsement by the U.S. Government.

Although this report is in the public domain, permission must be secured from the individual copyright owners to reproduce any copyrighted material contained within this report. 


\section{Contents}

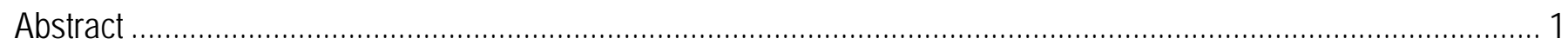

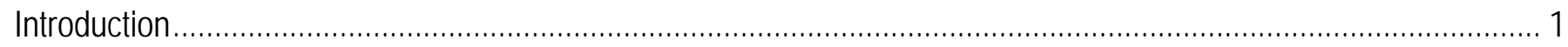

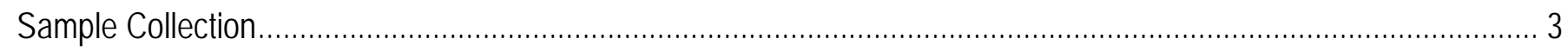

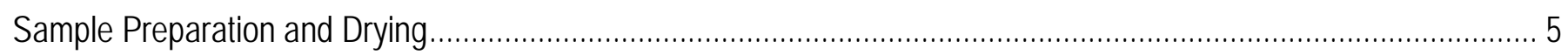

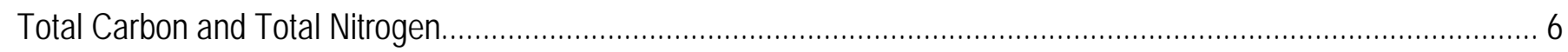

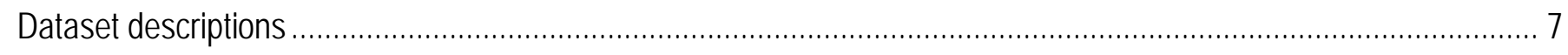

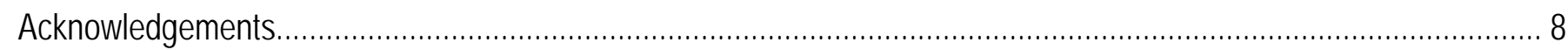

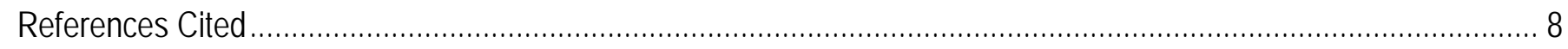

\section{Figure}

1. Aerial photograph of the Delta Junction area, Alaska, showing the locations of the four study sites

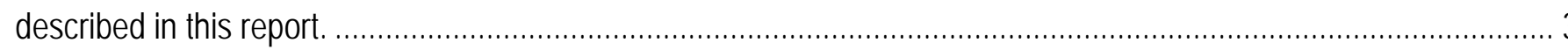

\section{Table}

1. Statistics of analyses for standards run on the Carlo Erba NA1500 elemental analyzer from June 2007 through July 2009. 


\title{
Soil Data from Different-Age Picea mariana Stands near
}

\section{Delta Junction, Alaska}

By Kristen L. Manies and Jennifer W. Harden

\begin{abstract}
One objective of the U.S. Geological Survey’s Fate of Carbon in Alaskan Landscapes (FOCAL) project is to study the effects of fire and soil drainage on soil carbon storage in boreal forests. For this purpose, the project has measured the soil carbon content in several chronosequences (time since disturbance) of various soil-drainage types. One such chronosequence near Delta Junction, Alaska was initially studied in 2000 and 2001 (Manies and others, 2004). Additional sites in the Delta Junction area were sampled in 2006 to expand the number of stand ages represented in the chronosequence. This report describes these additional sites, as well as the procedures used to describe, sample, and analyze the soils. We also present data tables containing, but not limited to, field descriptions, bulk density, moisture content, and total carbon (C) and total nitrogen (N) content.
\end{abstract}

\section{Introduction}

The U.S. Geological Survey’s (USGS) Fate of Carbon in Alaskan Landscapes (FOCAL) project was created in part to examine how disturbance affects carbon (C) storage within boreal forests, the recovery of $\mathrm{C}$ within these forests, and how this response varies with soil-drainage type. The chronosequence approach (space-for-time substitution) has proved to be a powerful tool to determine 
rates of C accumulation and loss (Harden and others, 1997; Trumbore and Harden, 1997).

Chronosequences have also been used to test models of soil thermal, hydrologic, and C dynamics (Yi and others, 2009; Zhuang and others, 2003). For this reason, the FOCAL project, in conjunction with many collaborators, has established several chronosequences within black spruce (Picea mariana (Mill.) BSP) dominated forests. The chronosequences are differentiated by region, soil moisture, and (or) disturbance type (for example, fire, loss of permafrost).

One such chronosequence, near the town of Delta Junction, Alaska (fig. 1), was part of a multidisciplinary effort to study the recovery of a forest after fire (Lui and Randerson, 2008; Mack and others, 2008; O'Neill and others, 2002, 2003; Treseder and others, 2004). This chronosequence is located in an area of discontinuous permafrost and within the Interior Bottomlands Ecoregion (Gallant and others, 1995), which is characterized by flat to nearly flat bottomlands covered by fluvial and eolian deposits. The average July temperature is $-19.2^{\circ} \mathrm{C}$ and the average July temperature is $16.0^{\circ} \mathrm{C}(1971$ 2000 data; see http://cdo.ncdc.noaa.gov/cgi-bin/climatenormals/climatenormals.pl, Big Delta station). Sites from the original chronosequence (Manies and others, 2004) included six moderately well to somewhat poorly drained ${ }^{1}$ sites $(2,7,45$, and $\sim 116$ years old) and three excessively to well drained sites (2, 14, and $\sim 61$ years old). To augment the soil data from the moderately well to somewhat poorly drained chronosequence, three new sites were sampled in 2006; in addition, the 45-year-old stand, which had low replication, was resampled. Information regarding this sampling effort is included in this report. Excel tables containing these data are also available, presented in a format similar to that used by Manies and others (2004) to facilitate data merging.

\footnotetext{
${ }^{1}$ More information on the soil drainage classifications as they pertain to Alaskan sites was presented by Harden and others (2003).
} 


\section{Sample Collection}

The study sites are located in the Donnelly Flats area (lat $63^{\circ} \mathrm{N}$., long $145^{\circ} \mathrm{W}$.), which is $\sim 95 \mathrm{mi}$ (153 km) southeast of Fairbanks, near Delta Junction (fig. 1). All samples are labeled with a code describing the site and location from which each samples was obtained. Except for D87W all sample

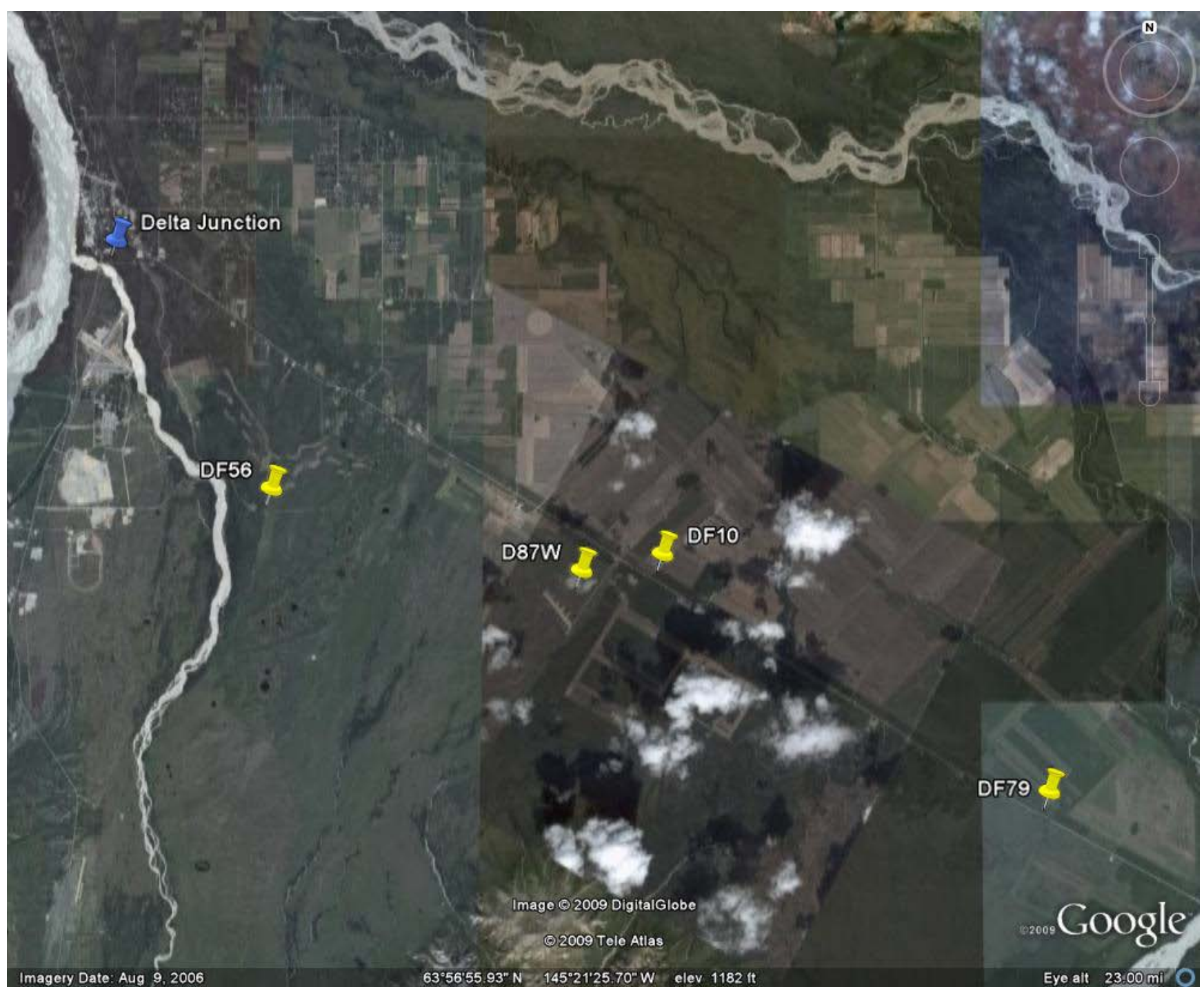

Figure 1. Aerial photograph of the Delta Junction area, Alaska, showing the locations of the four study sites described in this report. 
names begin with the same two letters (DF), representing Donnelly Flats, the area in which these sites are located, followed by two to three characters indicating the site name, which is usually represented by the year when the stand last burned. The first study site, DF56, which burned in 1956, is a somewhat poorly drained site that was sampled in 2001 (Manies and others, 2004) with limited replication.

Therefore, DF56 was included again in this sampling effort. The next study site, DF79, burned in 1979 and also is somewhat poorly drained. The third site, D87W, is located within the same burn scar as site DF87, which was sampled in 2001 (Manies and others, 2004), but is somewhat poorly drained. The fourth study site, DF10, which burned in 1920, is a moderately well drained site that has been studied by Teresa Hollingsworth (Hollingsworth and others, 2008), who referred to it as site TKN0123.

Soil was excavated to the depth of mineral soil. The soil profile was then divided into distinct horizons and labeled with two numbers representing the profile number and basal depth (in centimeters) of the sample. A decimal point separates the profile number from the basal depth; for example, "DF56 5.16” denotes a sample from the Donnelly Flats 1956 burn site, profile 5, with a basal depth of $16 \mathrm{~cm}$. Each sample was described according to US Department of Agriculture, Natural Resources Conservation Services (Staff, 1998) and Canadian (Committee, 1998) methodologies. We modified soil horizon codes according to the following scheme:

L Live moss, which is green and generally contains some leaf and needle litter

D Dead moss, which is composed of undecomposed or slightly decomposed dead moss. The deadmoss layer is characterized by fibric organic horizons that contain more moss than roots.

F Fibric (according to the Canadian soil system) or fibrous organic layers, which vary in degree of decomposition but within which roots are more abundant than recognizable moss parts. In most cases F layers would be considered Oi horizons (U.S. soil system) or upper duff (US Forest Service system). 
M Mesic (Canadian soil system) organic layers are moderately decomposed with few if any recognizable plant parts other than roots. M layers are generally considered Oe horizons (U.S. soil system) or lower duff (US Forest Service system).

$\mathrm{H} \quad$ Humic (Canadian soil system), or sapric organic layers, are highly decomposed. $\mathrm{H}$ layers smear upon rubbing and contain no recognizable plant parts. $\mathrm{H}$ layers are generally considered Oa horizons (U.S. soil system) or lower duff (US Forest Service soil system).

A Mineral soil that forms at the surface or below organic horizons (U.S. and Canadian soil systems), with less than 20 percent organic matter, as judged in the field

B Mineral soil that has formed below an A horizon (U.S. and Canadian soil systems), with little or none of its original rock structure

C Mineral soil that has been little affected by pedogenic processes (U.S. and Canadian soil systems)

LT Litter (dead leaves, twigs, and so on)

LN Lichen

Horizon codes could be further described with a lowercase "b" indicating that the horizon had been burned, which indicates anything from light scorching to deep charring. All soil profiles were subsampled by soil horizons. Subsamples were collected for bulk density, for analytical purposes, and to determine moisture content. Samples were collected by either cutting out an area of known volume or using a core of known volume (Nadler and Wein, 1998). Samples were placed in clean ziplock bags and shipped soon after collection to the USGS laboratory in Menlo Park, CA.

\section{Sample Preparation and Drying}

Upon the arrival of samples at the USGS laboratory, samples were inventoried by using the field sheets. Any discrepancy between field descriptions and laboratory observations was resolved before 
sample preparation began. All samples were placed on open shelves in an isolated room and allowed to air dry to a constant weight, as determined by weights obtained at least 1 week apart. Temperature during air drying ranged from $20^{\circ} \mathrm{C}$ to $30^{\circ} \mathrm{C}$. After air drying, samples were oven dried for 48 hours in a forced-draft oven. Samples that were classified as organic soil horizons (for example, moss, litter) were oven dried at $65^{\circ} \mathrm{C}$ to avoid loss or alteration of organic matter by oxidation or decomposition: the remaining samples were oven dried at $105^{\circ} \mathrm{C}$.

After oven drying, samples were thoroughly mixed and then split into subsamples for analysis and archiving. (Archive fractions of most of the samples described here are available by contacting J.W. Harden at the USGS office in Menlo Park, CA.) These samples were then processed in one of two ways, depending on horizon code. Mineral samples were gently crushed with a mortar and pestle, using care to break only aggregates, and then sieved through a 2-mm screen. Soil particles not passing the 2mm screen were removed, weighed, and saved separately. Soil passing the 2-mm screen was then ground by hand, using a mortar and pestle, to pass through a 60 -mesh $(0.246 \mathrm{~mm})$ screen. The ground material was mixed and placed in a labeled, glass sample bottle for subsequent analyses. Organic samples were weighed, and roots wider than $1 \mathrm{~cm}$ in diameter were removed, weighed, and saved separately. The remaining sample was then milled in an Udy Corp. Cyclone mill (Fort Collins, CO) to pass through a 0.5-mm screen. The milled sample was thoroughly mixed and a representative sample placed in a labeled, glass sample bottle for chemical analysis.

\section{Total Carbon and Total Nitrogen}

A Carlo Erba NA1500 elemental analyzer was used to determine total C and total N content. Because carbonates are rare in this area and mineral soil $\mathrm{pH}$ values from previous studies (Manies and others, 2004) were $\leq 7.0$, all, or the vast majority, of the soil C is considered organic (Staff, 1998). Samples were combusted in the presence of excess oxygen. The resulting sample gasses were swept in a 
continuous flow of helium through an oxidation furnace, followed by a reduction furnace, to yield $\mathrm{CO}_{2}$, $\mathrm{N}_{2}$, and water vapor. Water was removed by a chemical trap and $\mathrm{CO}_{2}$ and $\mathrm{N}_{2}$ were chromatographically separated before the quantification of C and N (Pella, 1990a, b).

All samples were compared to a main working standard, ethylenediamine tetra-acetic acid (EDTA). The chemical formula for this compound corresponds to a C content of 41.09 percent and an $\mathrm{N}$ content of 9.59 percent. Additional working standards were analyzed as samples in all runs to check consistency and overall precision (table 1). Peach tree leaves (SRM-1547), issued by the National Institute of Standards and Technology (NIST), were included in sample runs composed of organic soil. A marine sediment standard (MESS-1), issued by the Chemistry Division of the Canadian National Research Council, was included in runs comprised of mineral soil. Certified values for these standards were obtained from Becker (1990) and Govindaraju (1989), respectively.

\begin{tabular}{|l|r|r|r|r|r|r|}
\hline \multicolumn{1}{|c|}{ Standard Name } & \multicolumn{1}{|c|}{ Average } & $\begin{array}{c}\text { Standard } \\
\text { Deviation }\end{array}$ & $\mathbf{N}$ & Average & $\begin{array}{c}\text { Standard } \\
\text { Deviation }\end{array}$ & $\mathbf{N}$ \\
\hline SRM-1547 - peach leaves & 46.62 & 0.59 & 124 & 2.83 & 0.16 & 128 \\
\hline MESS-1 - marine sediment & 2.22 & 0.09 & 124 & 0.20 & 0.03 & 124 \\
\hline
\end{tabular}

[Certified values: MESS-1 = 2.99 percent C; SRM-1547 = 2.94 percent N.]

Table 1. Statistics of analyses for standards run on the Carlo Erba NA1500 elemental analyzer from June 2007 through July 2009.

\section{Dataset descriptions}

Five separate downloadable files contain the soil data collected from the eight study sites described in this report. The first file, Delta06_Site_Descriptions, which is in Adobe Reader format (pdf), describes the location of each study site and where, within a site, soils were sampled. The next file, Delta06_File_Descriptions, which is also an Adobe Reader file, describes in detail the data within the following three Microsoft Excel files: Delta06_Field_OFR, which contains field descriptions, such 
as root abundance, color, and soil texture, of the sampled soils; Delta06_Physical_OFR, which contains physical descriptions of the samples, such as volumetric field moisture and bulk density; and Delta06_Chemistry_OFR, which contains elemental C and elemental N content , and loss on ignition (LOI) values.

\section{Acknowledgements}

We thank Jon O’Donnell for his help in field sampling, Pedro Rodriguez for his assistance in the laboratory, and Teresa Nettleton Hollingsworth for sharing her site information. We also thank the USGS staff in Fairbanks, Alaska, including Mark Castor and Matt Schellekens, who provided logistical support. This research was supported by the USGS Earth Surface Dynamics Program.

\section{References Cited}

Becker, D.A., 1990, Homogeneity and evaluation of the new NIST leaf certified reference materials, in Proceeding of the International Conference on Nuclear Analytical Methods in the Life Sciences: Gaithersburg, MD National Institute of Standards, p. 571-577.

Committee, C.A.S.C., 1998, The Canadian system of soil classification (3rd ed.): Ontario, National Research Council Canada Research Press, 187 p.

Gallant, A.L., Binnian, E.F., Omernik, J.M., and Shasby, M.B., 1995, Ecoregions of Alaska: U.S. Geological Survey Professional Paper 1567, 73 p.

Govindaraju, K., 1989, Compliation of working value and sample description for 272 geostandards: Geostandards Newsletter, v. 13, p. 1-113.

Harden, J.W., Meier, R., Silapaswan, C., Swanson, D.K., and McGuire, A.D., 2003, Soil drainage and its potential for influencing wildfires in Alaska, in Galloway, J., ed., Studies by the U.S. 
Geological Survey in Alaska, 2001: U.S. Geological Survey Professional Paper 1678, p. 139144.

Harden, J.W., O'Neill, K.P., Trumbore, S.E., Veldhuis, H., and Stocks, B.J., 1997, Moss and soil contributions to the annual net carbon flux of a maturing boreal forest: Journal of Geophysical Research, v. 102, no. D24, p. 28805-28816.

Hollingsworth, T., Schuur, E., Chapin, F., and Walker, M., 2008, Plant community composition as a predictor of regional soil carbon storage in Alaskan boreal black spruce ecosystems: Ecosystems, v. 11, p. 629-642.

Lui, H., and Randerson, J.T., 2008, Interannual variability of surface energy exchange depends on stand age in a boreal forest fire chronosequence: Journal of Geophyiscal Research, v. 113, p. G01006.

Mack, M.C., Treseder, K.K., Manies, K.L., Harden, J.W., Schuur, E.A.G., Vogel, J.G., Randerson, J.T., and Chapin, F.S., III, 2008, Recovery of aboveground plant biomass and productivity after fire in mesic and dry black spruce forests of Interior Alaska: Ecosystems, v. 11, no. 2, p. 209-225.

Manies, K.L., Harden, J.W., Silva, S.R., Briggs, P.H., and Schmid, B.M., 2004, Soil data from Picea mariana stands near Delta Junction, Alaska of different ages and soil drainage types: U.S. Geological Survey Open-file Report 2004-1271, 19 p.

Nadler, I.A., and Wein, R.W., 1998, A new forest floor corer for rapid sampling, minimal disturbance and adequate precision: Silva Fennica, v. 32, no. 4, p. 373-381.

O'Neill, K.P., Kasischke, E.S., and Richter, D.D., 2002, Environmental controls on soil $\mathrm{CO}_{2}$ flux following fire in black spruce, white spruce, and aspen stand of interior Alaska: Canadian Journal of Forest Research, v. 32, p. 1525-1541. 
O'Neill, K.P., Kasischke, E.S., and Richter, D.D., 2003, Seasonal and decadal patterns of soil carbon uptake and emission along an age-sequence of burned black spruce stands in interior Alaska: Journal of Geophysical Research, v. 108, no. D1, p. doi:1029/2001JD000443.

Pella, E., 1990a, Elemental organic analysis. Part 1; Historical developments: American Laboratory, v. 22, no. 2, p. 116-125.

Pella, E., 1990b, Elemental organic analyzer. Part 2; State of the art: American Laboratory, v. 22, no. 12, p. 28-32.

Staff, S.S., 1998, Keys to Soil Taxonomy (8th ed.): Blacksburg, Virginia, Pocahontas Press, Inc., 599 p. Treseder, K.K., Mack, M.C., and Cross, A., 2004, Relationships among fires, fungi, and soil dynamics in Alaskan boreal forests: Ecological Applications, v. 14, no. 6, p. 1826-1838.

Trumbore, S.E., and Harden, J.W., 1997, Accumulation and turnover of carbon in organic and mineral soils of the BOREAS northern study site: Journal of Geophysical Research, v. 102, no. D24, p. 28817-28830.

Yi, S., McGuire, A.D., Harden, J., Kasischke, E., Manies, K., Hinzman, L., Liljedahl, A., Randerson, J., Liu, H., Romanovsky, V., Marchenko, S., and Kim, Y., 2009, Interactions between soil thermal and hydrological dynamics in the response of Alaska ecosystems to fire disturbance: Journal of Geophysical Research, v. 114, p. GO2015.

Zhuang, Q., McGuire, A.D., O`Neill, K.P., Harden, J.W., Romanovsky, V.E., and Yarie, J., 2003, Modeling soil thermal and carbon dynamics of a fire chronosequence in interior Alaska: Journal of Geophysical Research, v. 108, no. D1, p. 8147. 